\title{
DETERMINAN WILLINGNESS TO PAY RUMAH TIPE 36 KABUPATEN BANTUL
}

\author{
Nugraheni Rintasari, Rifki Khoirudin \\ Universitas Ahmad Dahlan Yogyakarta
}

\begin{abstract}
In general, willingness to pay (WTP) or desire to pay is defined as the amount that a consumer can pay to obtain a good or service. In this study, willingness to pay is devoted to the purchase of type 36 homes in Bantul District. This study intends to answer questions about the attributes that consumers favored related to type 36 homes in Bantul District. There are seven attributes tested in this research, namely location, security, facilities, payment, design, placement, and price. The location is divided into four options, namely proximity to the school, proximity to the workplace, proximity to shopping centers, and proximity to health facilities. For security, provided two options, namely guarded security guards and not guarded. The facility attributes are divided into three namely the availability of sports facilities, places of worship, and playground. For the payment offered two options, namely credit and cash. The design is divided into two namely luxury and minimalism. For the landing is divided into three, namely front, center, and rear. The last factor is price, divided into three namely $\mathrm{Rp} 300.000 .000,00, \mathrm{Rp} 350.000 .000,00$, and $\mathrm{Rp}$ 400.000.000,00.

The data are sourced from questionnaires distributed to 116 respondents in Bantul District, Special Province of Yogyakarta. Respondents of this research are employees of government and private organizations working in Bantul District. Further data is processed and analyzed using conjoint analysis. For all respondents who are permanent employees, both public and private with an income level ranging from Rp 3,000,000.00 to Rp 5.000.000,00 have willingness to pay for type 36 homes with consideration of location close to the workplace, guarded security, there are play facilities, can be paid on credit, luxury design with the location at the back, and the price ranges from $\operatorname{Rp} 300.000 .000,00$.
\end{abstract}

$\begin{array}{ll}\text { Keywords } & \text { : Willingness to Pay, Home Stay, House type } 36 \\ \text { Correspondence to } & \text { : rifki.khoirudin@ep.uad.ac.id }\end{array}$

ABSTRAK

Secara umum willingness to pay (WTP) atau keinginan untuk membayar didefinisikan sebagai jumlah yang dapat dibayarkan seorang konsumen untuk memperoleh suatu barang atau jasa. Dalam penelitian ini, willingness to pay dikhususkan pada pembelian rumah tipe 36 di Kabupaten Bantul. Penelitian ini bermaksud menjawab pertanyaan mengenai atribut yang disukai konsumen terkait rumah tipe 36 di Kabupaten Bantul. Ada tujuh atribut yang diuji dalam penelitian ini, yaitu lokasi, keamanan, fasilitas, pembayaran, desain, perletakan, dan harga. Lokasi dibagi menjadi empat pilihan, yaitu kedekatan dengan sekolah, kedekatan dengan tempat kerja, kedekatan 
dengan pusat perbelanjaan, dan kedekatan dengan fasilitas kesehatan. Untuk keamanan, disediakan dua pilihan, yaitu dijaga satpam dan tidak dijaga satpam. Atribut fasilitas dibagi menjadi tiga yaitu ketersediaan fasilitas olahraga, tempat ibadah, dan tempat bermain. Untuk pembayaran ditawarkan dua pilihan, yaitu kredit dan tunai. Desain dibagi menjadi dua yaitu mewah dan minimalis. Untuk perletakkan dibagi menjadi tiga, yaitu depan, tengah, dan belakang. Faktor terakhir yaitu harga, dibagi menjadi tiga yaitu Rp 300.000.000,00, Rp 350.000.000,00, dan Rp 400.000.000,00.

Data bersumber dari kuesioner yang disebarkan kepada 116 responden di Kabupaten Bantul, Propinsi Daerah Istimewa Yogyakarta. Responden penelitian ini adalah karyawan organisasi pemerintah maupun swasta yang bekerja di Kabupaten Bantul. Selanjutnya data diolah dan dianalisis menggunakan analisis konjoin. Untuk responden yang keseluruhannya merupakan pegawai tetap, baik negeri maupun swasta dengan tingkat penghasilan berkisar antara Rp 3.000.000,00 hingga $\mathrm{Rp} 5.000 .000,00$ memiliki willingness to pay untuk rumah tipe 36 dengan pertimbangan lokasi yang dekat dengan tempat kerja, dijaga satpam, terdapat fasilitas bermain, dapat dibayar secara kredit, desain mewah dengan letak di belakang, dan harga berkisar Rp $300.000 .000,00$.

\section{Kata kunci Korespondensi \\ : Willingness to Pay, Rumah Tinggal, Rumah tipe 36 \\ : rifki.khoirudin@ep.uad.ac.id}

\section{PENDAHULUAN / INTRODUCTION}

Pemerintah membutuhkan cost accounting dalam penetapan tariff biaya maupun anggaran. Ada lima aktivitas biaya yang harus dilakukan dalam penentuan biaya. Kelima aktivitas itu adalah cost finding, cost recording, cost analyzing, strategic cost reduction, dan cost reporting (Mardiasmo, 2004). Cost finding merupakan proses mengakumulasi data biaya yang dibutuhkan untuk menghasilkan produk atau jasa tertentu. Penelitian ini bermaksud untuk melakukan cost finding terkait willingness to pay rumah tipe 36. Penggolongan kebutuhan manusia terdiri dari tiga macam yaitu kebutuhan primer, sekunder dan tersier. Kebutuhan primer adalah kebutuhan yang harus dipenuhi seorang manusia dalam menjalani kehidupannya. Kebutuhan primer tersebut adalah sandang, pangan, dan papan (Reksohadiprodjo dan Karseno, 2012:73). Dalam rangka pemenuhan papan maka diperlukan perumahan. Yudhohusodo (1991: 1) menyatakan bahwa perumahan mempunyai fungsi ekonomi yang sangat penting bagi manusia karena rumah merupakan salah satu investasi jangka panjang yang dapat memperkokoh jaminan hidup di masa depan (Fajria, 2009:1). Kebutuhan manusia terhadap rumah tinggal selalu mengalami peningkatan dari waktu ke waktu, terutama di wilayah perkotaan. Permasalahan yang terjadi adalah peningkatan populasi manusia tidak sebanding dengan lahan yang tersedia.

Perumahan merupakan suatu produk seperti produk lainnya yang memiliki atribut fisik dan non fisik. Oleh karena itu, hasrat untuk membeli rumah seseorang akan dihadapkan pada banyak pertimbangan. Keputusan calon pembeli dalam membeli suatu produk termasuk perumahan akan selalu memaksimalkan kepuasan, kemakmuran, dan sesuai dengan batasan anggaran yang ada. Smith, dkk. (1992) dalam Triwahyuningsih (2007:5) berpendapat bahwa meskipun pada umumnya properti dinilai lebih berdasarkan pada atribut fisik dibandingkan pada persepsi konsumen tetapi untuk properti perumahan, dan real estate lainnya yang berkaitan dengan konsumen 
seperti pertokoan akan lebih mempertimbangkan faktor non keuangan dan persepsi konsumen.

Kabupaten Bantul merupakan salah satu kabupaten di wilayah Provinsi D.I. Yogyakarta. Kabupaten Bantul terletak di sebelah Selatan Provinsi Daerah Istimewa Yogyakarta, berbatasan dengan :

Sebelah Utara : Kota Yogyakarta dan Kabupaten Sleman

Sebelah Selatan : Samudera Indonesia Kidul

Sebelah Timur : Kabupaten Gunung

Sebelah Barat : Kabupaten Kulon Progo

Kabupaten Bantul terletak antara $07^{\circ}$ 44' 04" - 08 00' 27" Lintang Selatan dan $110^{\circ} 12^{\prime} 34^{\prime \prime}$ - $110^{\circ} 31^{\prime}$ 08" Bujur Timur. Luas wilayah Kabupaten Bantul 508,85 Km2 (15,90 5 dari Luas wilayah Propinsi DIY) dengan topografi sebagai dataran rendah $40 \%$ dan lebih dari separonya $(60 \%)$ daerah perbukitan yang kurang subur, secara garis besar terdiri dari :

1. Bagian Barat, adalah daerah landai yang kurang serta perbukitan yang membujur dari Utara ke Selatan seluas $89,86 \mathrm{~km} 2 \quad(17,73 \quad \% \quad$ dari seluruh wilayah)

2. Bagian Tengah, adalah daerah datar dan landai merupakan daerah pertanian yang subur seluas $210.94 \mathrm{~km} 2$ (41,62\%).

3. Bagian Timur, adalah daerah yang landai, miring dan terjal yang keadaannya masih lebih baik dari daerah bagian Barat, seluas 206,05 km2 $(40,65 \%)$.

4. Bagian Selatan, adalah sebenarnya merupakan bagian dari daerah bagian Tengah dengan keadaan alamnya yang berpasir dan sedikir berlagun, terbentang di Pantai Selatan dari Kecamatan Srandakan, Sanden dan Kretek.

Kabupaten Bantul secara administratif terdiri dari 17 kecamatan, 75 desa dan 933 pedukuhan (Tabel 1.1). Desa-desa di Kabupaten Bantul dibagi lagi berdasarkan statusnya menjadi desa pedesaan (rural area) dan desa perkotaan (urban area). Kecamatan Dlingo mempunyai wilayah paling luas, yaitu $55,87 \mathrm{Km} 2$. Sedangkan jumlah desa dan pedukuhan yang terbanyak terdapat di Kecamatan Imogiri dengan delapan desa dan 72. Berdasarkan RDTRK dan Perda mengenai batas wilayah kota, maka status desa dapat dipisahkan sebagai desa perdesaan dan perkotaan.

Jumlah penduduk di Kabupaten Bantul terus mengalami peningkatan, dengan pertumbuhan selama kurun waktu dua dekade yang terus meningkat. Laju pertumbuhan penduduk dengan pertumbuhan penduduk tertinggi di kecamatan Banguntapan, Kasihan dan Piyungan. Ketiga kecamatan ini merupakan penyumbang pertumbuhan penduduk paling banyak, dan berdasarkan keadaan wilayah ketiga kecamatan ini merupakan daerah yang pesat perkembangan perumahannya.

Berdasar Gambar 1.1 terlihat bahwa piramida penduduk Kabupaten Bantul besar di tengah, yangmenunjukan bahwa penduduk didominasi penduduk usia muda. Prosentasi penduduk yang berusia antara 15-45 tahun mendominasi keadaan demografi penduduk Kabupatan Bantul. Keadaan ini mengindikasikan bahwa Kabupaten Bantul memerlukan tingkat hunian yang tinggi. Tingkat hunian ini diwujudkan dengan kebijakan pengadaan perumahan di Kabupaten Bantul.

Pemerintah mempunyai peran penting dalam penyediaan kebutuhan perumahan yang layak untuk masyarakat. Pemerintah Indonesia juga mempunyai peran penting dalam pengendalian dan menjaga keseimbangan transaksi properti perumahan. Kebijakan tingkat bunga yang rendah, inflasi yang terkendali dan pertumbuhan pendapatan 
dapat mendukung kondisi bagi pertumbuhan industri properti dan penyediaan perumahan bagi masyarakat.

\section{Gambar.1.1 Piramida Penduduk Hasil Proyeksi Sensus Penduduk di Kabupaten Bantul , 2012}

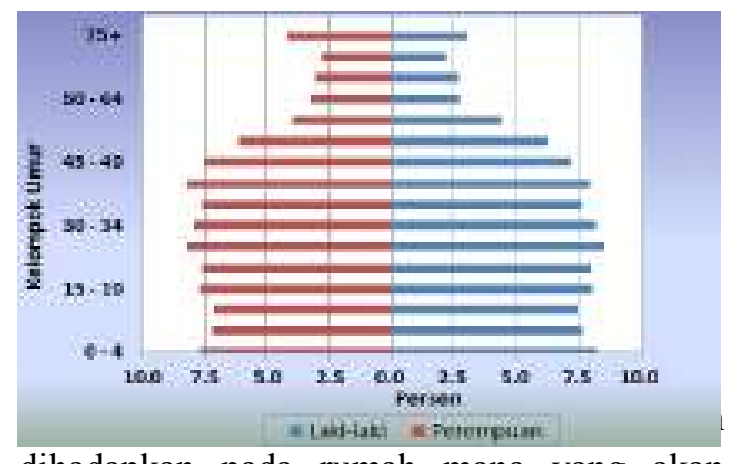

dihadapkan pada rumah mana yang akan dipilih oleh seorang calon pembeli. Preferensi menjadi penting bagi konsumen untuk menentukan pembelian suatu barang termasuk rumah tinggal. Preferensi konsumen menjadi sesuatu yang penting ketika konsumen dihadapkan pada keterbatasan pendapatan (Drachman, 2009: 3). Arsyad (2000: 109) menjelaskan bahwa dalam teori perilaku konsumen, konsumen mengkonsumsi lebih sedikit daripada yang diinginkan karena pengeluaran dibatasli oleh pendapatan.

Konsumen akan memilih suatu barang dengan memaksimalkan kepuasannya tetapi tetap dibatasi oleh anggaran yang ada. Hasrat calon pembeli membeli rumah tinggal tidak hanya dipengaruhi oleh harga namun faktor lain seperti faktor lokasi, yakni kedekatan dengan tempat kerja dan sarana transportasi pun berpengaruh terhadap pemilihan rumah tinggal (Tan, 2011: 14). Faktor harga bukan menjadi satu-satunya pertimbangan dalam pemilihan rumah tinggal tetapi juga terkait lokasi, fasilitas, tipe rumah, maupun faktor keamanan.

Permasalahan dalam penelitian ini adalah permintaan (demand) rumah yang tinggi diikuti dengan jumlah penawaran (supply) rumah tipe 36 yang tinggi namun jika dilihat dari lama waktu penawarannya ternyata tidak semua rumah tipe 36 laku. Maka terjadi gap antara permintaan rumah dengan rumah tipe 36 yang ditawarkan di pasar properti Kabupaten Bantul. Tidak semua rumah tipe 36 yang ditawarkan dibeli oleh pembeli. Perkembangan jumlah manusia dan jumlah lahan yang terbatas, membuat kebutuhan perumahan tidak mencukupi permintaan rumah. Ketidakcukupan ini juga didorong oleh naiknya harga rumah dan tidak diikuti oleh naiknya pendapatan masyarakat. Keinginan membeli rumah akan terhalang oleh ketidakmampuan masyarakat membeli rumah.

Keputusan calon pembeli membeli rumah tipe 36 sangat dipengaruhi oleh atribut yang melekat pada rumah tersebut. Atribut yang menjadi preferensi calon pembeli rumah tipe 36 berbeda-beda pada tiap individu. Berdasarkan hal tersebut, penelitian ini akan menganalisis pola atribut yang menjadi preferensi calon pembeli (Willingness to Pay) dalam membeli rumah tipe 36 di Kabupaten Bantul.

\section{TINJAUAN PUSTAKA}

Leszczyńska (2014) meneliti kesediaan konsumen untuk membeli produk yang ramah lingkungan. Penelitian ini menyajikan hasil penelitian mengenai kesediaan membayar (WTP) untuk produk ramah lingkungan yang dipilih. Tujuan penelitian adalah evaluasi kesediaan membayar (WTP) untuk produk ramah lingkungan dengan melihat keterkaitan antara kemauan dan nilai-nilai individu dengan membandingkan manfaat produk yang dirasakan. Metoda penelitian dilakukan untuk menilai WTP dengan membandingkan nilai produk ramah lingkungan dangan produk non-ramah lingkungan.
A.
Landasan Teoritis
1.
Teori Perilaku Konsumen 
Konsumsi adalah pengeluaran oleh rumah tangga atas barang dan jasa. Elemen elemen pokok dari konsumsi dari konsumsi di antara yang paling penting adalah perurmahan. Sedangkan konsumen adalah seseorang yang menggunakan barang atau jasa. Saat ini konsumen begitu dimanjakan dengan berbagai produk yang dapat dipilih untuk memenuhi kebutuhan. Era produsen mengendalikan konsumen telah berlalu dan telah digantikan dengan era dimana konsumen memegang kendali. Konsumen yang mendikte produk apa yang seharusnya diproduksi oleh perusahaan. Perusahaan harus berfokus pada konsumen, konsumen adalah bagian terpenting dari perusahaan. Oleh karena itu perusahaan perlu mengerti bagaimana konsumennya berperilaku.

Faktor - faktor yang mempengaruhi perilaku konsumen (Griffin dan Ebert, 2007:289) yaitu :

a.Pengaruh budaya, mencakup budaya, subkultur, dan kelas sosial.

b. Pengaruh psikologis, mencakup motivasi, persepsi, kemampuan belajar, dan sikap individu.

c.Pengaruh pribadi, mencakup gaya hidup, kepribadian, dan status ekonomi.

d. Pengaruh sosial, mencakup keluarga, pendapat pemimpin (orang yang pendapatnya diterima oleh orang lain), dan kelompok referensi lainnya seperti teman, rekan kerja, dan rekan seprofesi.

Secara umum willingness to pay (WTP) atau keinginan untuk membayar didefinisikan sebagai jumlah yang dapat dibayarkan seorang konsumen untuk memperoleh suatu barang atau jasa. Whitehead (2005) menyatakan bahwa WTP adalah harga maksimum dari suatu barang yang ingin dibeli oleh konsumen pada waktu tertentu. Sedangkan Tan (2011) menekankan pengertian WTP pada berapa kesanggupan konsumen untuk membeli suatu barang. WTP itu sebenarnya adalah harga pada tingkat konsumen yang merefleksikan nilai barang atau jasa dan pengorbanan untuk memperolehnya (Scarpa, 2010). Disisi lain, WTP ditujukan untuk mengetahui daya beli konsumen berdasarkan persepsi konsumen (Millock, 2002).

Hal ini didukung oleh Arsyad ( 2000: 97-98) yang menyatakan bahwa dalam teori perilaku konsumen terdapat 3 pendekatan untuk menganalisis perilaku pilihan konsumen yaitu :

a. Pendekatan Utilitas, menganggap bahwa keputusan konsumen yang diperoleh dari pengkonsumsian barangbarang dan jasa dapat diukur dengan cara sama seperti untuk berat atau tinggi badan seseorang (kuantitatif/kardinal).

b. Pendekatan kurva indiferens, menganggap bahwa tingkat kepuasan atau utilitas yang diperoleh konsumen dari pengkonsumsian barang - barang dan jasa hanya bisa dihitung dengan pengukuran ordinal.

c. Pendekatan atribut, menganggap bahwa yang diperhatikan konsumen bukanlah produk secara fisik, tetapi atribut yang terkandung di dalam produk tersebut. Atribut suatu barang adalah semua jasa yang dihasilkan dari penggunaan dan atau kepemilikan barang tersebut. Arsyad (2000: 116117) menambahkan bahwa dalam pendekatan atribut, diasumsikan bahwa rumah tangga telah membagi - bagi anggaran untuk setiap kelompok kebutuhan. Konsumen mendapatkan kepuasan dari penggunaan atribut tetapi konsumen harus membeli produk untuk memperoleh atribut tersebut. Jadi produk itu merupakan alat untuk menyampaikan atribut dalam proses konsumsi. Setiap barang memberikan satu atribut atau lebih dalam suatu perbandingan tertentu. 


\section{Teori Pendekatan Atribut}

Zinas dan Jusan (2010) dalam penelitiannya menyatakan atribut dapat didefinisikan sebagai fitur intrinsik dan fisik, sifat atau karakteristik yang mendifinisikan sebuah produk atau orang. Ada dua jenis atribut yaitu concrete attribute dan abstract attribute. Concrete attribute didefinisikan sebagai nilai yang dirasakan atau manfaat yang didapat dari sesuatu, dapat juga diartikan sebagai karakteristik yang relatif tidak berwujud, seperti gaya dan merek. Abstract attribute didefinisikan karakteristik fisik secara langsung jelas dari suatu produk, misalnya harga, warna, dan berat. Maka dapat disimpulkan jika diterapkan untuk konsumsi perumahan, concrete attribute adalah manfaat yang dirasakan oleh pembeli atas rumah yang telah dimiliki sedangkan abstract attribute adalah harga, bentuk, desain, dan item-item lain yang dapat diukur dan dilihat secara fisik dari rumah yang dimiliki.

Arsyad (2000: 116) mengatakan pendekatan atribut didasarkan pada asumsi bahwa perhatian konsumen bukan terhadap produk secara fisik, tapi lebih ditujukan kepada atribut produk yang bersangkutan. Pendekatan ini menggunakan analisis utilitas yang digabungkan dengan analisis kurva indiferens. Atribut merupakan semua jasa yang dihasilkan dari penggunaan produk atau pemilikan suatu barang.

\section{Atribut dan level yang digunakan}

Penelitian ini akan menganalisis dan menentukan preferensi calon pembeli dalam membeli rumah tipe 36 dengan menggunakan stimuli dari berbagai kombinasi atribut dan level. Atribut merupakan jasa yang diperoleh dari penggunaan dan atau kepemilikan suatu barang, sedangkan level merupakan bagian dari atribut. Atribut yang dipertimbangkan mempengaruhi preferensi konsumen dalam pembelian rumah dalam penelitian ini mengacu pada penelitian terdahulu.

a. Lokasi

Bond (2000) menyatakan lokasi memiliki nilai kepentingan kedua. Sedangkan Triwahyuningsih (2007) menyatakan atribut yang paling dominan adalah lokasi yang terdiri dari aksesibilitas, keamanan, dan jenis jalan.

b. Keamanan

Triwahyuningsih (2007) menyatakan semua konsumen menyukai sistem keamanan yang dijaga oleh satpam. Sedangkan Perdhana (2003) menyatakan keamanan memiliki nilai kepentingan pada urutan keempat. Hasil wawancara menunjukkan kualitas penjagaan satpam selama 24 jam sangat dipertimbangkan oleh konsumen.

c. Fasilitas

Anggraeni (2011) menyatakan atribut fasilitas menempati urutan ketiga terpenting.

d. Desain

Imam, Pieng, dan Gan (2012) menyatakan atribut yang dianggap relevan berpengaruh terhadap keputusan seseorang memilih rumah adalah desain dan furniture.

e. Harga

Imam, Pieng, dan Gan (2012) menyatakan atribut yang paling relevan salah satunya adalah harga. Sedangkan Wong (2013) menyatakan harga yang lebih rendah berhubungan dengan rata-rata utilitas yang lebih tinggi.

\section{Pengertian Rumah}

Menurut Undang - Undang Republik Indonesia Nomor 4 Tahun 1992 tentang perumahan dan pemukiman, perumahan adalah kelompok rumah yang berfungsi sebagai lingkungan tempat tinggal atau lingkungan hunian yang dilengkapi dengan prasarana dan sarana lingkungan. Pemukiman adalah bagian dari lingkungan hidup diluar kawasan lindung, baik yang berupa kawasan perkotaan maupun pedesaan yang berfungsi 
sebagai lingkungan tempat tinggal atau lingkungan hunian dan tempat kegiatan yang mendukung perikehidupan dan penghidupan.

\section{Faktor - faktor yang mempengaruhi nilai properti}

Hidayati dan Harjanto (2001: 3-4) menyatakan bahwa suatu properti akan mempunyai nilai jika memiliki ciri - ciri sebagai berikut:

a. Permintaan (demand) yaitu suatu properti memiliki nilai jika mereka dibutuhkan oleh pembeli potensial yang mempunyai kemampuan keuangan dan keinginan pembayaran terhadap barang tersebut.

b. Utilitas (utility), yaitu yang berkaitan dengan keuntungan yang dihasilkan oleh suatu properti, dan sejauhmana suatu properti tersebut dapat memenuhi kebutuhan dan keinginan pembeli potensial.

c. Kelangkaan (scarcity) yakni merujuk pada realtivitas tingkat pemasokan properti (supply) yang dapat memenuhi kebutuhan pembeli potensial; dan

d. Transferability yang merujuk pada proses transfer hak properti dari suatu pihak ke pihak lain.

\section{METODOLOGI}

\section{PENELITIAN/METHODS}

Tema penelitian ini adalah pola-pola atribut yang mempengaruhi hasrat calon pembeli untuk membeli rumah tipe 36 di Kabupaten Bantul. Unit penelitian ini adalah Dosen dan Karyawan Fakultas Ekonomi Universitas Ahmad Dahlan. Pemilihan populasi ini didasarkan oleh beberapa faktor yakni Dosen dan Karyawan Fakultas Ekonomi Universitas Ahmad Dahlan berasal dari berbagai daerah, serta memiliki pendapatan yang berbeda - beda.

Batasan- dan definisi operasional dari atribut yang digunakan dalam penelitian ini dibutuhkan agar interpretasi hasil analisis tidak diartikan secara luas. Batasan-batasan yang digunakan adalah :

a.Rumah adalah bangunan yang berfungsi sebagai tempat tinggal atau hunian dan sarana pembinaan keluarga (Undang Undang No. 4 Tahun 1992 tentang perumahan)

b. Perumahan yang dimaksud dalam penelitian ini adalah sejalan dengan Undang - Undang No. 4 Tahun 1992 tentang perumahan, yaitu sekelompok rumah yang berfungsi sebagai lingkungan tempat tinggal atau hunian yang dilengkapi dengan prasarana dan sarana lingkungan baik yang dibangun oleh pemerintah maupun swasta.

c.Atribut merupakan jasa yang diperoleh dari penggunaan dan atau pemilikan suatu barang

d. Level merupakan bagian dari atribut

e.Stimuli merupakan kombinasi dari level dan atribut

Definisi operasional dari atribut dan level yang digunakan dalam penelitian in $\mathrm{i}$ adalah.

a.Variabel dependen yang digunakan dalam penelitian ini adalah hasrat untuk memilih rumah tipe 36 yang akan dibeli, yaitu urutan prioritas terhadap kombinasi atribut rumah dari yang paling disukai sampai yang paling tidak disukai.

b. Variabel bebas yang digunakan dalam penelitian ini yaitu.

- Lokasi merupakan kedekatan dengan fasilitas umum. Atribut ini terdiri dari 4 level, yaitu kedekatan dengan tempat kerja, sekolah, fasilitas kesehatan, dan pusat perbelanjaan

- Keamanan yaitu keberadaan penjagaan satpam dalam suatu perumahan. Atribut ini terdiri dari 2 level, yaitu dijaga satpam dan tidak dijaga satpam.

- Fasilitas yaitu fasilitas yang terdapat dalam komplek perumahan. Atribut ini terdiri 
dari 3 level, yaitu tempat ibadah, tempat bermain, dan lapangan olahraga.

- Desain yaitu desain yang melekat pada rumah. Desain terdiri dari 2 level, yaitu minimalis dan mewah.

- Harga yaitu harga yang ditentukan oleh pengembang pada transaksi jual beli rumah tipe 36 di Kabupaten Bantul.

Definisi operasional dari data demografi responden dan kisaran besarannya dalam penelitian ini adalah.

1. Jenis Kelamin, yaitu jenis kelamin responden yang dikelompokkan menjadi 2 kelompok yaitu pria dan wanita.

2. Pekerjaan yaitu pekerjaan yang melekat pada responden saat kuosioner diedarkan dan dikelompokkan menjadi 2 yaitu Dosen dan Karyawan.

3. Pendapatan Keluarga yaitu jumlah penghasilan responden dan pasangan (suami/istri) dari pekerjaan utama maupun pekerjaan sampingan selama satu bulan yang dihitung dalam satuan rupiah, dikelompokkan menjadi 3 yaitu : lebih kecil dari Rp3.000.000, Rp3.000.000 - Rp6.000.000, dan lebih dari Rp6.000.000.

\section{A. Jenis dan sumber data}

Data yang digunakan dalam penelitian ini adalah data kualitatif. Menurut Kuncoro (2001: 213) data kualitatif adalah data yang tidak dapat diukur dalam skala numerik. Setelah itu data kualitatif ini dikuantitatifkan agar dapat diproses dengan statistik yaitu dengan mengklasifikasikan dalam bentuk kategori baik berupa jumlah nominal (data yang dinyatakan dalam bentuk kategori) maaupun data ordinal (data yang dinyatakan dalam bentuk kategori namun posisi data tidak sama derajatnya karena dinyatakan dalam skala peringkat).

Data yang digunakan dalam penelitian adalah data primer yang merupakan hasil pengisian kuosioner oleh responden. Responden dalam penelitian ini adalah
Karyawan Pemda dan Organisasi Swasta di Kabupaten Bantul sebanyak 114 orang.

\section{B. Metode pengumpulan data}

Data diperoleh dari kuosioner yang dibagikan kepada responden. Daftar pertanyaan dalam kuosioner dibagi menjadi dua kelompok, yaitu:

1. Kelompok pertama berupa pertanyaan terbuka, yaitu pertanyaan yang dirancang sedemikian rupa untuk mengetahui data responden.

2. Kelompok kedua berupa pertanyaan tertutup yang dirancang untuk mengetahui atribut yang berpengaruh terhadap hasrat untuk membeli rumah tipe 36 .

\section{Metode pengambilan sampel}

Dalam penelitian ini teknik pengambilan sampel yang digunakan adalah purposive sampling (pengambilan sampel bertujuan). Populasi adalah masyarakat yang bekerja di Kota Yogyak. Kriteria sampel adalah responden yang sudah bekerja. Penelitian ini dilakukan di dua tempat, yaitu di Kantor Satuan Kerja Perangkat Daerah (SKPD) Kabupaten Bantul dan Kampus Universitas Ahmad Dahlan. SKPD Kabupaten Bantul mewakili pegawai negeri sipil sedangkan Universitas Ahmad Dahlan mewakili pegawai swasta. Alasan pengambilan sampel berupa pegawai negeri ataupun swasta adalah mereka memiliki gaji tetap sehingga cukup bankable.

\section{E. Metode Analisis}

Analisis konjoin merupakan teknik yang banyak digunakan untuk menggambarakan dan memprediksi preferensi individu dan pilihan perilaku (Molin, Oppewal, dan Timmermans, 2002). Analisis konjoin adalah teknik multivariate yang khusus digunakan untuk memahami bagaimana responden mengembangkan preferensi terhadap suatu produk atau jasa. 
Hal ini didasarkan pada premis bahwa konsumen menilai produk/jasa/ide (riil atau hipotesis) dengan cara mengkombinasikan jumlah nilai dari masing - masing atribut yang terpisah. Ghozali (2011) menyatakan dalam penelitiannya riset pemasaran analisis konjoin digunakan untuk mengetahui bagaimana preferensi konsumen terhadap berbagai desain produk.

Menurut Supranto (2004: 200-216) langkah - langkah yang harus dilakukan dalam menggunakan analisis konjoin adalah sebagai berikut.

\section{a.Merumuskan Masalah}

Merupakan mengenali masalah atau mendefinisikan atribut dengan tingkatan/level masing - masing yang dipergunakan untuk membentuk stimulus (kombinasi/atribut).

b. Membentuk stimulus

Pada penelitian ini pembentukan stimulus dilakukan dengan menggunakan profil penuh (full-profile procedure). Stimuli ini kemudian digunakan dalam kuosioner untuk diurutkan oleh responden. Untuk mengurangi jumlah stimuli yang banyak dapat digunakan reduksi dengan memakai bantuan orthogonal array dengan bantuan program SPSS. Desain ini mengasumsikan bahwa semua interaksi yang tidak penting dapat diabaikan.

c.Menentukan bentuk data masukan

Data yang digunakan dalam penelitian ini merupakan data kualitatif (non-matrix).
Hal ini dikarenakan data merupakan kuosioner yang diisi oleh responden yang diminta untuk membuat rangking terhadap stimuli yang telah dibuat. Rangking diurutkan dengan stimuli yang paling disukai hingga stimuli yang paling tidak disukai.

d. Mengolah data dalam format analisis konjoin dengan bantuan SPSS 21.

\section{HASIL PENELITIAN/RESULTS}

Penelitian ini dilakukan pada 116 responden, sebanyak 60 berasal dari karyawan swasta yang diwakili karyawan pada Universitas Ahmad Dahlan dan 56 berasal dari pegawai negeri yang diwakili karyawan pada SKPD Kabupaten Bantul. Sebanyak 54\% responden berjenis kelamin pria dan $46 \%$ berjenis kelamin wanita. Distribusi responden berdasarkan jenis kelamin ditunjukkan dalam tabel 5.1. Dari 116 responden, sebanyak $22 \%$ belum menikah dan 78\% sudah menikah. Distribusi responden berdasarkan status pernikahan ditunjukkan dalam tabel 5.2. Untuk rentang usia responden, mayoritas berusia antara 30-40 tahun. Distribusi responden berdasarkan usia ditunjukkan dalam tabel 5.3. Dari 116 responden, mayoritas memiliki pendapatan antara $\mathrm{Rp}$ 3.000.000,00 sampai dengan $\mathrm{Rp}$ 6.000.000,00. Distribusi responden ditunjukkan dalam tabel 5.4.

Tabel 5.1

Distribusi Responden Berdasarkan Jenis Kelamin

\begin{tabular}{|l|l|l|}
\hline No & Jenis Kelamin & Jumlah \\
\hline 1 & Pria & 63 \\
\hline 2 & Wanita & 53 \\
\hline
\end{tabular}

Tabel 5.2 
Balance Vol. XV No. 2 | Juli 2018

Distribusi Responden Berdasarkan Status Pernikahan

\begin{tabular}{|l|l|l|}
\hline No & Status Pernikahan & Jumlah \\
\hline 1 & Belum Menikah & 25 \\
\hline 2 & Menikah & 91 \\
\hline
\end{tabular}

116

Tabel 5.3

Distribusi Responden Berdasarkan Rentang Usia

\begin{tabular}{|l|l|l|}
\hline No & Rentang Usia & Jumlah \\
\hline & $<30$ tahun & 29 \\
\hline & $30-40$ tahun & 36 \\
\hline & $41-50$ tahun & 29 \\
\hline & $>50$ tahun & 22 \\
\hline & & 116 \\
\hline
\end{tabular}

Penelitian ini menggunakan analisis konjoin untuk menggambarkan preferensi individu. Untuk menuju analisis konjoin, pertama dilakukan perumusan masalah terlebih dahulu dan menentukan atribut- atributnya. Preferensi yang akan diteliti adalah rumah tipe 36 dengan gambaran lebih jelas mengenai atribut dijelaskan dalam tabel 5.5 .

Tabel 5.4

Distribusi Responden Berdasarkan Rentang Pendapatan

\begin{tabular}{|l|l|l|}
\hline \multirow{2}{*}{$\mathrm{N}$} & Rentang Pendapatan & Jumlah \\
\hline & $<30$ tahun Rp 3.000.000,00 & 42 \\
\hline & Rp 3.000.000,00-Rp 6.000.000,00 & 59 \\
\hline & $>\operatorname{Rp~} 6.000 .000,00$ & 15 \\
\hline & & 116 \\
\hline
\end{tabular}

Penelitian ini menggunakan analisis konjoin untuk menentukan preferensi konsumen terkait willingness to pay rumah tipe 36. Setelah dirumuskan atribut dan kombinasi dari pilihan konsumen selanjutnya dilakukan proses analisis konjoin dengan bantuan SPSS 21. Hasil dari analisis konjoin ditunjukkan dalam Tabel 5.7. Dari tabel 5.7 menunjukkan bahwa willingness to pay rumah tipe 36 dari faktor lokasi, konsumen lebih memilih rumah yang dekat dengan tempat kerja. Hal itu ditunjukkan dengan angka utilities estimate sebesar 0,753 yang mengungguli faktor kedekatan lokasi dengan sekolah, fasilitas kesehatan, dan tempat belanja. Bahkan kedekatan lokasi dengan sekolah, fasilitas kesehatan, dan tempat belanja menjadi faktor yang tidak disukai konsumen. Hal ini ditunjukkan dengan angka utilities estimate yang negatif.

Untuk faktor keamanan, konsumen lebih memilih dijaga satpam. Hal ini ditunjukkan dengan utilities estimate sebesar 0,091. Faktor pembayaran, konsumen lebih memilih membayar secara kredit. Hal ini ditunjukkan dengan utilities estimates sebesar 0,081 . Untuk faktor fasilitas, konsumen lebih mengutamakan adanya tempat olahraga dan disusul fasilitas tempat ibadah. Angka utilities estimate kedua faktor di atas menunjukkan 0,265 dan 0,163 membuktikan 
bahwa keberadaan tempat bermain dan tempat olahraga menjadi pilihan konsumen dibanding tempat bermain yang ditunjukkan dengan angka utilities estimate 0,177 dan 0,146 .

Desain mewah menjadi pilihan konsumen yang ditunjukkan dengan angka utitilies estimate sebesar 0,257. Untuk perletakkan, konsumen lebih memilih berada di tengah daripada bagian depan dan belakang. Angka utilities estimate sebesar 0,031 untuk perletakkan belakang mendukung pernyataan tersebut. Faktor harga, dari tiga pilihan yang diberikan ternyata konsumen memilih harga yang paling tinggi yaitu Rp 300.000.000,00 dengan angka utilities estimate 0,207.

Dari tujuh faktor yang dijadikan pertimbangan konsumen terkait willingness to pay rumah tipe 36 , pertimbangan terbesar ada di faktor lokasi yang ditunjukkan dengan angka importance value sebesar 38,008 pada tabel 5.8. Faktor kedua yaitu desain diikuti dengan faktor fasilitas. Selanjutnya harga, keamanan, dan pembayaran menjadi pertimbangan berikutnya. Dan faktor perletakan menjadi pertimbangan terakhir di antara faktor-faktor yang lain di atas.

Dari pembahasan di atas, dapat diketahui bahwa willingness to pay rumah tipe 36 akan mempertimbangkan lokasi yang dekat dengan tempat kerja, dijaga satpam, terdapat fasilitas bermain, dapat dibayar secara kredit, desain mewah dengan letak di belakang, dan harga berkisar Rp 300.000.000,00.

Hasil penelitian ini sejalan dengan penelitian Tri Wahyuningsih (2007) yang menyatakan bahwa atribut yang paling dominan adalah lokasi yang terdiri dari aksesibilitas, keamanan, dan jenis jalan. Selain itu dalam penelitian tersebut disebutkan bahwa semua konsumen menyukai sistem keamanan yang dijaga oleh satpam. Hal tersebut sejalan dengan penelitian ini. Perdhana (2003) menyatakan bahwa keamanan memiliki urutan ke-empat sedangkan dalam penelitian ini menempati urutan kelima.

Anggraeni (2011) menyatakan bahwa fasilitas menempati urutan ketiga terpenting. Hasil penelitian tersebut sejalan dengan penelitian ini. Harga dikatakan oleh Imam, Pieng, dan Gan (2012) serta Wong (2013) sebagai atribut yang cukup relevan. Hal tersebut sejalan dengan penelitian ini bahwa harga menempati urutan keempat.

Urutan atribut prioritas menurut responden dalam penelitian ini adalah:
1. Lokasi
2. Desain
3. Fasilitas
4. Harga
5. Keamanan
6. Pembayaran
7. Perletakan

Lokasi menjadi atribut yang dianggap penting oleh responden. Terutama kedekatan dengan tempat kerja. Hanya saja, bagi kantorkantor yang terletak di pusat kota tentu kesulitan bagi pengembang untuk membangun perumahan di sana. Oleh karena itu desain dan fasilitas kemudian menjadi nilai jual yang layak dipertimbangkan. Seluruh responden merupakan masyarakat bekerja dan pegawai tetap tetapi harga minimal dan pembayaran kredit tetap menjadi pilihan prioritas.

Tabel 5.8 menunjukkan angka korelasi dengan pengujian Pearson's Correlation yaitu sebesar 0,992. Pengukuran korelasi digunakan untuk membuktikan adanya hubungan yang kuat antara estimasi dengan aktual atau ada predictive accuracy yang tinggi pada proses konjoin baik secara Pearsons maupun Kendall. Hasil pengujian menunjukkan angka 0,829 yang artinya faktor-faktor di atas mampu menunjukkan korelasi yang kuat mengenai willingness to pay rumah tipe 36 . 
Tabel 5.5

Atribut dan Tarif Atribut

\begin{tabular}{|r|l|l|}
\hline \multicolumn{1}{|c|}{ No } & Atribut & Tarif Atribut \\
\hline 1 & Lokasi & (Kedekatan dengan) Sekolah \\
\hline & & (Kedekatan dengan) Tempat Kerja \\
\hline & & (Kedekatan dengan) Pusat Perbelanjaan \\
\hline 2 & Keamanan & Dijaga Satpam \\
\hline & & Tidak dijaga satpam \\
\hline 3 & Pembayaran & Kredit \\
\hline & & Tunai \\
\hline 4 & Fasilitas & Lapangan Olahraga \\
\hline & & Tempat Ibadah \\
\hline & & Tempat Bermain \\
\hline 5 & Desain & Mewah \\
\hline & & Minimalis \\
\hline 6 & Perletakan & Depan \\
\hline & & Tengah \\
\hline & & Belakang \\
\hline 7 & Harga & Rp300.000.000,00 \\
\hline & & Rp350.000.000,00 \\
\hline & & Rp400.000.000,00 \\
\hline
\end{tabular}

Tabel 5.6

Utilities Willingness to Pay

\begin{tabular}{|c|c|c|c|}
\hline \multicolumn{4}{|l|}{ Utilities } \\
\hline & & $\begin{array}{l}\text { Utility } \\
\text { Estimate }\end{array}$ & Error \\
\hline \multirow{4}{*}{ LOKASI } & Dekat dengan Sekolah &,- 034 & ,309 \\
\hline & Dekat dengan Tempat Kerja & ,753 & ,380 \\
\hline & Dekat dengan Tempat Perbelanjaan &,- 309 & ,309 \\
\hline & Dekat dengan Fasilitas Kesehatan &,- 411 & ,362 \\
\hline \multirow{2}{*}{ KEAMANAN } & Dijaga Satpam & ,091 & ,202 \\
\hline & Tidak Dijaga Satpam &,- 091 & ,202 \\
\hline \multirow{2}{*}{ PEMBAYARAN } & KREDIT & ,081 & ,198 \\
\hline & TUNAI &,- 081 & ,198 \\
\hline \multirow{3}{*}{ FASILITAS } & Ada Lapangan Olahraga & , 146 & ,270 \\
\hline & Ada Tempat Ibadah &,- 323 & ,295 \\
\hline & Ada Tempat Bermain & 177 & ,371 \\
\hline \multirow{2}{*}{ DESAIN } & Mewah & 257 & ,204 \\
\hline & Minimalis &,- 257 & ,204 \\
\hline \multirow{2}{*}{ PERLETAKAN } & Depan &,- 053 & ,244 \\
\hline & Tengah & ,031 & ,279 \\
\hline
\end{tabular}


Balance Vol. XV No. 2 | Juli 2018

\begin{tabular}{|c|l|c|r|}
\hline & Belakang &, 023 &, 285 \\
\hline \multirow{3}{*}{ HARGA } & $\operatorname{Rp~300.000.000,00~}$ &, 207 &, 319 \\
\cline { 2 - 4 } & $\operatorname{Rp~350.000.000,00}$ &,- 250 &, 369 \\
\cline { 2 - 4 } & $\operatorname{Rp~400.000.000,00}$ &, 043 &, 287 \\
\hline (Constant) & & 8,446 &, 210 \\
\hline
\end{tabular}

(sumber: data primer yang diolah)

Tabel 5.7

Importance Value

\begin{tabular}{|l|l|l|}
\hline No & Faktor & Importance Value \\
\hline 1 & Lokasi & 38,008 \\
\hline 2 & Keamanan & 5,923 \\
\hline 3 & Pembayaran & 5,298 \\
\hline 4 & Fasilitas & 16,325 \\
\hline 5 & Desain & 16,799 \\
\hline 6 & Perletakkan & 2,735 \\
\hline 7 & Harga & 14,912 \\
\hline
\end{tabular}

Tabel 5.8

Hasil pengujian korelasi

\begin{tabular}{|l|l|l|}
\hline & & \\
\hline Pearson's R & 0,829 & 0,000 \\
\hline Kendall's tau & 0,561 & 0,000 \\
\hline
\end{tabular}

(sumber: data primer yang diolah)

SIMPULAN, SARAN, DAN KETERBATASAN PENELITIAN

Penelitian ini menjawab permasalahan mengenai willing responden yang keseluruhannya merupakan pegawai tetap, baik negeri maupun swasta dengan tingkat penghasilan berkisar antara Rp 3.000.000,00 hingga Rp 5.000.000,00 memiliki willingness to pay untuk rumah tipe 36 dengan pertimbangan lokasi yang dekat dengan tempat kerja, dijaga satpam, terdapat fasilitas bermain, dapat dibayar secara kredit, desain mewah dengan letak di belakang, dan harga berkisar Rp 300.000.000,00.

Keterbatasan penelitian ini adalah kombinasi yang sudah ditentukan oleh peneliti bisa jadi bukan pilihan responden. Perlu disampaikan kombinasi lain tanpa harus membuat responden menjadi bingung dan bias dalam menjawab pertanyaan.

\section{DAFTAR PUSTAKA}

Anggreini, Febri, 2011, “Analisis Preferensi Konsumen Rumah di Bale Agung Residence Kabupaten Sleman", Tesis $S$-2, Program Pascasarjana,Universitas Gadjah Mada.

Arsyad, Lincolin, 2000, Ekonomi Manajerial: Ekonomi Mikro Terapan untuk Manajemen Bisnis, edisi 3, BPFE, Yogyakarta.

Bond, Sandy, 2000, “Conjoint Analysis: Assessing Buyer Preferences for Property Attributes to Assist with the Estimation of Land Contamination Stigma", Australian Land Economic Review, volume 1, 1-33.

Drachman, Zakiyah, 2009, "Preferensi Konsumen dalam Membeli Rumah di Kota Ambon Pasc Konflik”, Tesis S-2, 
Program Pascasarjana, Universitas Gadjah Mada.

Fajria, Dini Lestari, 2009, "Preferensi Konsumen dalam Membeli Rumah, Tipe Menengah Sederhana di Kota Bandung", Tesis S-2, Program Pascasarjana, Universitas Gadjah Mada.

Ghozali, Imam, 2011, Aplikasi Analisis Multivariate dengan Program IBM SPSS 19, Badan Penerbit Universitas Dipenogoro, Semarang

Griffin, Ricky W. and Ebert, Ronald J., 2007, Bisnis, Edisi kedelapan, alih Bahasa Sita Wardhani, Erlangga, Jakarta

Hidayati, Wahyu dan Harjanto, B., 2001, Konsep Dasar Penilaian Properti, Edisi pertama, BPFE, Yogyakarta.

Iman, Abdul H M., Pieng, Fu Y, and Gan, Christopher, 2012, "A Conjoint Analysis of Buyers' Preferences for Residential Property", International Real Estate Review, Vol. 15 No. 1: pp. $73-105$.

Leszczyńska, Agnieszka (2014). Willingness to Pay for Green Products vs Ecological Value System. International Journal of Synergy and Research, Vol. 3, p. 6777

Mardiasmo, 2004. Akuntansi Sektor Publik. Andi Offset. Yogyakarta.

Millock, K., Hansen, L.G. Wier, M., Anderson, L.M. (2002). Willingness to Pay for Organic products: A Comparison between Survey Data and Panel Data from Denmark, $A K F$ Denmark.

Perdhana, Putri, 2013, "Pola Atribut yang Mempengaruhi Preferensi Konsumen dalam Membeli Rumah Tipe Menengah di Kecamatan Tembalang Kota Semarang Tahun 2012", Tesis $S$ 2, Program Pascasarjana, Universitas Gadjah Mada.

Reksohadiprodjo, Sukanto dan Karseno, A. R., 1997. Ekonomi Perkotaan. Yogyakarta : BP Fakultas Ekonomi UGM.

Scarpa, R., and Willis, K., (2010). Willingness-topay for renewable energy: Primary and discretionary choice of British households' for micro-generation technologies, Energy Economics, Vol. 32, 129-136

Supranto, J., 2004, Analisis multivariate: Arti dan Interpretasi, Rineka Cipta, Jakarta.

Tan,Teck Hong, 2011. Measuring the willingness to pay for houses in a sustainable neighborhood, MPRA Paper No. 30446, 09:49 UTC

Triwahyuningsih, Nanik, 2007, "Preferensi Konsumen dalam Membeli Rumah di Wilayah Perkotaan Kabupaten Sleman", Tesis S-2, Program Pascasarjana, Universitas Gadjah Mada.

Undang - Undang Republik Indonesia Nomor 4 Tahun 1992

Whitehead, J.C., 2005, Combining Willingness to Pay and Behavior Data With Limited Information, Resource and Energy Economics, Vol. 27, 143-15

Wong, Maisy, 2013, "Estimating Ethnic Preferences Using Ethnic Housing Quotas in Singapore", Review of Economic Studies 1-37.

www.bps.go.id

Yudohusodo, Siswono, dkk. (1991), Rumah untuk Seluruh Rakyat, INKOPPOL, Jakarta

Zinas, Bako Zachariah dan Mahmud Bin Mohd Juan, 2010, Choice Behaviour of Housing Attributes: Theory and Measurement. FSPU UiTM. 